\title{
Comparison between different methods of breast implant volume choice and degree of postoperative satisfaction
}

\section{Comparação entre diferentes métodos de escolha de volume de implantes mamários e o grau de satisfação pós-operatório}

\author{
Rafael Daibert de Souza Motta ${ }^{1}$; Ana Claudia Weck Roxo ${ }^{1}$; Fabio Xerfan Nahas ${ }^{1}$; Fernando Serra-Guimarães ${ }^{1}$
}

\begin{abstract}
A B S T R A C T
Objectives: to assess the degree of patient satisfaction after undergoing breast augmentation and compare three different, easy, inexpensive and universal methods of preoperative choice of breast implant volume. Methods: a prospective study was carried out at University Hospital Pedro Ernesto of State University of Rio de Janeiro, in 94 women from Rio de Janeiro, aged 18 to 49 years, submitted to breast augmentation mammaplasty with breast implant due to hypomastia. All implants were textured, with a round base and high projection and were introduced into the retroglandular space through an inframammary access. The patients were divided into three groups: Control, silicone and MamaSize ${ }^{\circledR}$, with 44, 25 and 25 patients, respectively. Satisfaction questionnaires were applied in the pre and postoperative periods by the same evaluator, through the visual analogue scale, in which ' 0 ' meant very unsatisfied and '100' very satisfied for the four variables: shape, size, symmetry and consistency. The degree of satisfaction with the surgical scar was also assessed in the postoperative period. Results: when the preoperative and postoperative satisfaction levels were compared, there was a difference in all variables for the three groups, with statistical significance. However, when the postoperative data were compared with each other, there was no significant difference. The degree of satisfaction with the surgical scar was high. Conclusion: the augmentation mammaplasty with breast implant had a high index of satisfaction among patients. However, there was no difference in the degree of satisfaction in the postoperative period between the three methodologies of breast volume measurement.
\end{abstract}

Keywords: Mammaplasty. Patient Satisfaction. Plastic Surgery. Breast Implants. Size Perception.

\section{INTRODUCTION}

A ugmentation mammaplasty is currently the most often performed cosmetic surgery worldwide ${ }^{1}$. In Brazil, it is the second most often performed esthetic plastic surgery, corresponding to $13.64 \%$ of procedures ${ }^{1}$. Thus, complication rates, which are relatively low, become high in absolute numbers. There are many articles in the literature on the subject, however, most of them are retrospective or multicenter studies that do not focus on the choice of breast volume. Additionally, when they describe the choice of implant, they do so through a single methodology, without any prospective comparisons between the other existing methods ${ }^{2-7}$. The population evaluated in these studies generally consists of women from the northern hemisphere, where culture and customs closely correlate with the aspirations and perspectives about the surgery $2,3,7-10$. Although Brazil was the second in the world in esthetic plastic surgery in 2016, there have been few studies that evaluated this cultural issue in the country'.

The choice of breast implant size is one of several variables that must be determined prior to the surgical procedure. Guiding the patient is important in situations where reoperation is mandatory, such as when a late seroma is evidenced, for instance ${ }^{11}$. On the other hand, breast implant change, which is currently one of the main causes of reoperation, should also be discussed with the patient, and needs to be reduced, through a more complete preoperative approach ${ }^{3,6,9,12}$.

Few studies have been performed in which the patient actively participates in the choice of breast implant volume and evaluates her degree of satisfaction in the postoperative period. Therefore, it is necessary to assess an easy, inexpensive and universal model of breast implant volume measurement, which involves the

1 - State University of Rio de Janeiro, Postgraduate Program in Pathophysiology and Surgical Sciences, Rio de Janeiro, RJ, Brazil. 
patient's decision power, together with the surgeon, and with excellent postoperative results.

This study aims at assessing the degree of satisfaction of patients submitted to augmentation mammaplasty, as well as to compare three different, easy, inexpensive and universal methods of preoperative choice of breast implant volume.

\section{METHODS}

This was a prospective study, carried out at the University Hospital Pedro Ernesto of the State University of Rio de Janeiro (UERJ), with 94 women from Rio de Janeiro, aged between 18 and 49 years, submitted to augmentation mammaplasty due to hypomastia. The non-inclusion factors were: patients under 18 years of age, those with indication for mastopexy, smokers, patients with psychiatric disorders, those with a prior history of breast surgery and those with systemic diseases. The exclusion factors were: breastfeeding or pregnancy during the study, failure to perform the preoperative study and loss of postoperative follow-up.

The implants were introduced in the retroglandular space through an inframammary access. Patients were systematically divided into three groups, for convenience: Control Group with 44 patients, MamaSize ${ }^{\circledR}$ Experimental Group with 25 patients and Silicone Experimental Group with 25 patients. All implants were textured, with a round base and high projection.

In the control group, breast implants were chosen through anthropometric measurements ${ }^{13}$. By measuring the basis and thickness of the patient's breast parenchyma, the silicone implant basis is calculated. Subsequently, the product that corresponds to that base is chosen.

In the MamaSize ${ }^{\circledR}$ Experiment group, the implants were chosen according to the MamaSize ${ }^{\circledR 14}$ meter, where the mold is placed behind a bra without a cup, in front of a full-length mirror (Figure 1). The intersection between the mold of the patient's breast size (vertical axis) and that chosen by the patient (horizontal axis) shows the volume to be placed (Figure 1). Aiming to be similar to silicone molds, the following correlation was made between the volume chosen through MamaSize ${ }^{\circledR}$ and the available volume to be placed: $170=175 \mathrm{~mL}$, $220=215 \mathrm{~mL}, 240=235 \mathrm{~mL}, 260=255 \mathrm{~mL}, 290=285 \mathrm{~mL}$, $300=305 \mathrm{~mL}, 330=325 \mathrm{~mL}, 360=355 \mathrm{~mL}$.

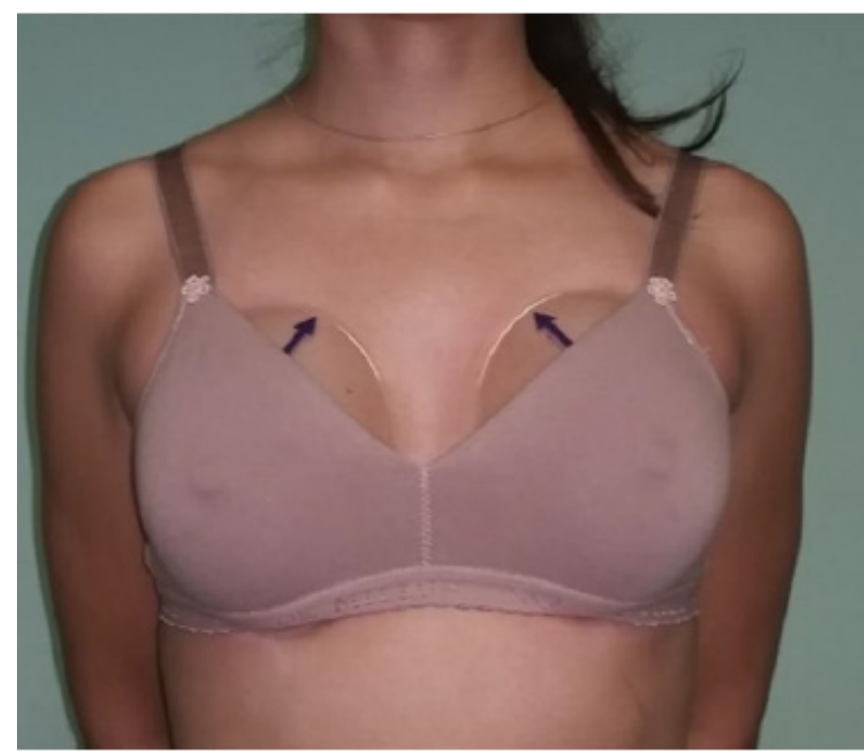

Considered breast size

\begin{tabular}{|c|c|c|c|c|c|c|c|}
\hline \multirow{2}{*}{$\frac{\mathbb{N}}{\omega}$} & 38 & 40 & 42 & 44 & 45 & 48 & 48 \\
\hline & & 140 & 170 & 220 & 290 & 300 & . \\
\hline 40 & & & 170 & 220 & 260 & 300 & 360 \\
\hline \multirow{2}{*}{$\begin{array}{l}\overrightarrow{\mathrm{D}} \\
\stackrel{\mathrm{D}}{\mathrm{D}} \\
\end{array}$} & & & & 150 & 240 & 260 & 330 \\
\hline & & & & & 150 & 215 & 300 \\
\hline \multirow{2}{*}{ 를 } & & & & & & & \\
\hline & & & & & & & \\
\hline 与 & & & & & & & \\
\hline
\end{tabular}
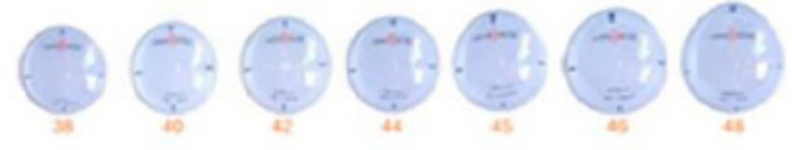

Figure 1. MamaSize $($ Mold

In the Experimental Silicone Group, the following volume molds were used: $175 \mathrm{~mL}, 195 \mathrm{~mL}, 215 \mathrm{~mL}, 235 \mathrm{~mL}$, $255 \mathrm{~mL}, 285 \mathrm{~mL}, 305 \mathrm{~mL}, 325 \mathrm{~mL}$ and $355 \mathrm{~mL}$. The patient chose the volume using the breast implant measurer that reproduced them in their shapes and dimensions, using a bra without a cup, in front of a full-length mirror. After the choice, new tests with volumes were performed, one above and one below the chosen one, for the ratification of the decision.

Satisfaction questionnaires were applied in the pre- and postoperative periods by the same evaluator, using a visual analogue scale (Figure 2), where 0 meant 
very unsatisfied and 100 meant very satisfied for the four scar, only the postoperative period was evaluated ${ }^{15,16}$. variables: shape, size, symmetry, and consistency. For the

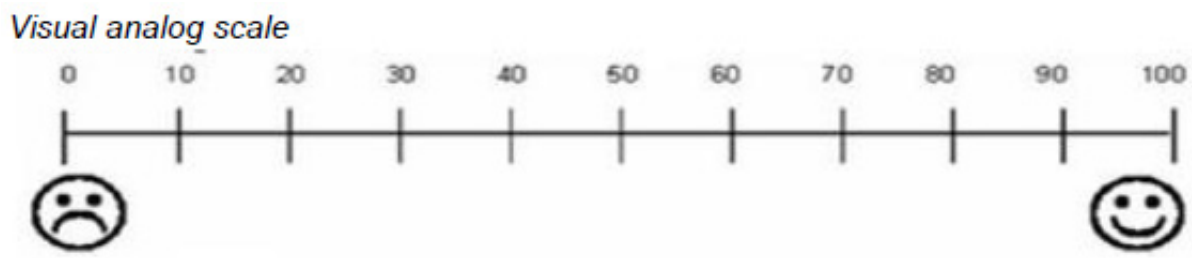

In the preoperative period

According to the scale above, grade questions 1 through 4 according to your degree of satisfaction:

1- How do you feel about your breast shape today?

2- How do you feel about your breast size today?

3- How do you feel about your breast symmetry today?

4- How do you feel about your breast consistency today?

In the postoperative period of the $1^{\text {st }}$ month $/ 6^{\text {th }}$ month $/ 12^{\text {th }}$ month

According to the scale above, grade questions 1 through 4 according to your degree of satisfaction:

1- How do you feel about your new breast shape today?

2- How do you feel about your new breast size today?

3- How do you feel about your new breast symmetry today?

4- How do you feel about your new breast consistency today?

5- How do you feel about your breast scar today?

Figure 2. Visual Analog Scale and Questionnaire

The study, classified as a longitudinal and analytical case-control one, has a convenience sample, in which the definition of cases and controls is systematized. We analyzed 25 cases as Silicone, 25 cases as MamaSize ${ }^{\circledR}$ and 44 cases as Control. The first analysis used descriptive statistics. Frequency, relative frequency and $95 \%$ confidence intervals were used to depict the variables in descriptive tables, aiming to understand the groups' profile in relation to the performed research. All variables were tested in relation to their normality, i.e., to verify whether they come from a population with normal distribution, using the Shapiro-Wilks test. To verify whether the anthropometric variables and the research variables were from the same population, regardless of the group (Silicone, MamaSize ${ }^{\circledR}$ and Control), the ANOVA statistical test was used, or Kruskal-Wallis test, when the data were not from the Normal population. To verify the existence of significant changes during the follow-up period, the $t$ test was used, or the Wilcoxon test, when the data are not from the Normal population. For the assessment of the statistical tests, a significance level of 0.05 (5\%) was used, in which p-value $<0.05$ was considered significant for the analyses.

The computer programs Microsoft Excel 2010 and Software R, version 3.3.1 (R Core Team 2015, Vienna, Austria) were used for data organization, creation of tables/charts and statistical analysis.

The study was submitted to Plataforma Brasil, under CAAE number 13986513.2.0000.5259 version 1 , and was approved on 05/21/2013, under Opinion Number 285716. All patients signed the free and informed consent form for the surgical procedure and for the study participation.

\section{RESULTS}

The mean values of the patients' age, BMI and mammary basis did not show statistical difference between the three groups. The mean age of the groups was 28 years, the mean BMI was $21.91\left(\mathrm{~kg} / \mathrm{m}^{2}\right)$ and the mean value of the mammary basis was $11.62 \mathrm{~cm}$. The results of the mean implant volume, when statistically evaluated, 
showed no difference between them: MamaSize ${ }^{\circledR}$ Group: 284,04mL; Implant Group: 280.83mL; Control Group: 287.85mL (p-value: 0.6761).

Table 1 shows the comparison of the variables shape, size, symmetry and consistency in the preoperative and postoperative periods ( $12^{\text {th }}$ month), showing a statistical difference. However, when the groups were compared between them regarding the four variables in the $12^{\text {th }}$ postoperative month, there was no statistical difference. When comparing the patients' scores for the scar variable between the $1^{\text {st }}$ and $12^{\text {th }}$ month in all three groups, no statistical significance was observed.

Table 1. Comparison of the Control, Silicone and MamaSize ${ }^{\circledR}$ groups in the preoperative and postoperative periods (12 $2^{\text {th }}$ month).

\begin{tabular}{|c|c|c|c|c|}
\hline \multirow[b]{2}{*}{ VARIABLES } & \multicolumn{4}{|c|}{ PERIODS } \\
\hline & GROUP & Preoperative & $\begin{array}{c}12^{\text {th }} \text { postoperative } \\
\text { Month }\end{array}$ & P-value \\
\hline \multirow{3}{*}{ Shape } & Control & $38.07(30.25-46.86)$ & $98.29(96.78-99.80)$ & $<0.0001$ \\
\hline & Silicone & $37.60(25.67-49.53)$ & $96.40(93.77-99.03)$ & $<0.0001$ \\
\hline & MamaSize ${ }^{\circledR}$ & $42.00(31.54-52.46)$ & $97.60(95.13-100.07)$ & $<0.0001$ \\
\hline \multirow{3}{*}{ Size } & Control & $21.82(16.61-28.13)$ & $95.00(91.56-98.44)$ & $<0.0001$ \\
\hline & Silicone & $22.40(13.30-31.50)$ & $93.40(89.79-97.01)$ & $<0.0001$ \\
\hline & MamaSize ${ }^{\circledR}$ & $19.20(10.87-27.53)$ & 87.60 (80.77-94.47) & $<0.0001$ \\
\hline \multirow{3}{*}{ Symmetry } & Control & $68.07(58.38-79.25)$ & $90.92(86.25-95.59)$ & 0.0012 \\
\hline & Silicone & $62.80(48.28-77.32)$ & $92.80(87.40-98.62)$ & 0.0020 \\
\hline & MamaSize $^{\circledR}$ & $62.16(48.81-75.51)$ & $95.20(90.72-99.68)$ & 0.0002 \\
\hline \multirow{3}{*}{ Consistency } & Control & $52.73(43.11-63.21)$ & $97.50(94.81-100.19)$ & $<0.0001$ \\
\hline & Silicone & $63.20(49.52-76.88)$ & $94.00(89.38-98.62)$ & 0.0003 \\
\hline & MamaSize $^{\circledR}$ & $58.80(46.00-71.60)$ & $98.80(96.99-100.61)$ & $<0.0001$ \\
\hline
\end{tabular}

Figure 3 shows the preoperative and the $12^{\text {th }}$ month postoperative aspects of a patient, in the control group, with a $285 \mathrm{~mL}$ implant. Figure 4 shows a patient in the preoperative and in the $12^{\text {th }}$ month postoperative periods, with a $285 \mathrm{~mL}$ implant, and the methodology of choice with the silicone mold in the Silicone group. Figure 5 shows a patient in the preoperative and in the $12^{\text {th }}$ month postoperative periods, with a $285 \mathrm{~mL}$ implant, and the methodology of choice with the MamaSize ${ }^{\circledR}$ mold.

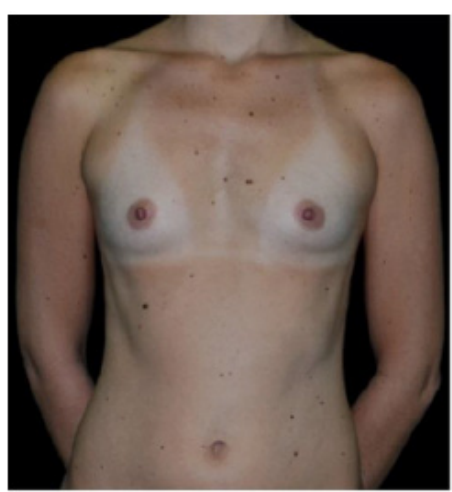

A

Figure 3. Control group: preoperative (A); postoperative (B).



A

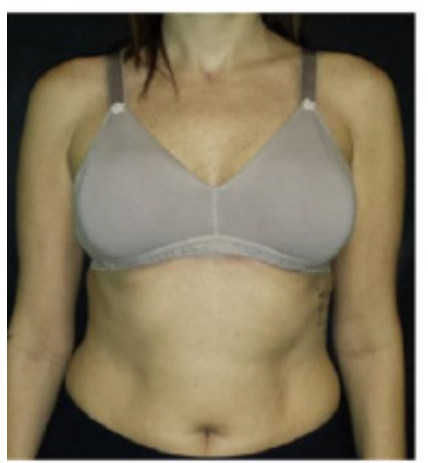

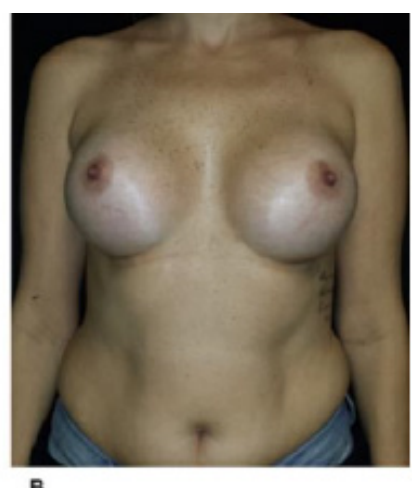

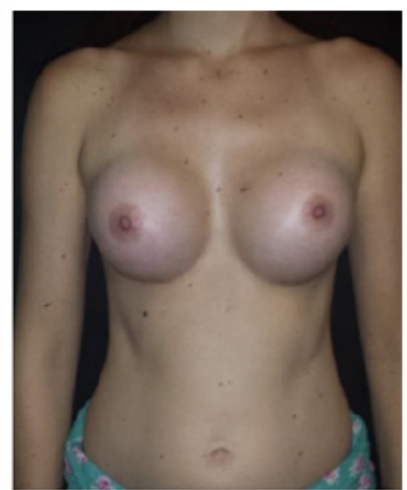

Figure 4. Silicone Group: Preoperative $(A), 12^{\text {th }}$ month (B), Mold (C). 

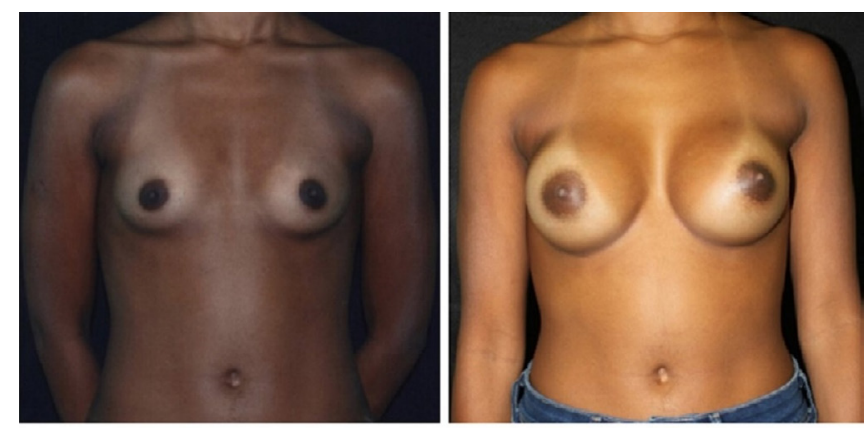

A

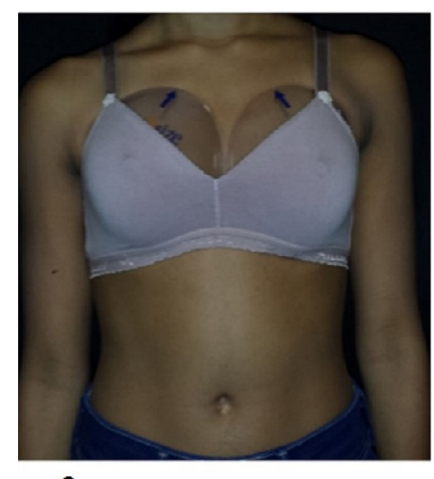

$\mathbf{B}$

Figure 5. MamaSize ${ }^{\circledR}$ group: preoperative $(A)$, $12^{\text {th }}$ month $(B)$, MamaSize ${ }^{(}(C)$.

\section{DISCUSSION}

Because it is the second most often performed esthetic plastic surgery in Brazil and the first in the USA, augmentation mammaplasty reoperation rates due to volume exchange, which would firstly be relatively low $(1.9 \% \text { to } 5.4 \%)^{9,12}$, are significantly higher in absolute numbers. Therefore, predicting this volume and, thus, avoiding reoperations, in addition to adding less morbidity to the patient, would avoid an expense that, in the US for instance, is around US $\$ .5770 .00$ per reoperation ${ }^{9,12}$. The literature shows that up to $20 \%$ of patients in the postoperative period of breast augmentation surgery complain of breast volume, although not all of them want to reoperate ${ }^{17}$.

There are articles that study preoperative types of breast implant volume measurement. However, despite showing good results, no studies were found comparing them prospectively $4,5,13,14,17-19$. Thus, what would be the measurement methodology of preoperative breast implant volume with the lowest cost and the best benefit? Is there any difference in the postoperative evaluation by the patients, if they use these different preoperative methods discussed in the literature? As satisfaction is closely related to the patient's expectations, and these vary according to the local culture, we believe that the Brazilian patients should be studied. Therefore, this study was then created, which utilized three easy, inexpensive methodologies widely used in the literature to compare the degree of patient satisfaction in the preand postoperative periods.

The sample results confirm the stereotype of these patients: they are young, with a mean age of 28 years and normal BMI, whose main dissatisfaction is breast size. The mean mammary basis was $11.62 \mathrm{~cm}$, with an anticipated implant volume of approximately $285 \mathrm{~mL}$. Therefore, anthropometrically similar patients were studied and compared.

When patient satisfaction was evaluated before and one year after the surgery, there was a significant increase in the degree of satisfaction in all groups, with statistical significance. This fact supports studies in the literature that show the excellent results of this intervention ${ }^{2,3,5}$. However, when comparing the degree of satisfaction in the postoperative evaluation between the three studied groups, there was no statistical difference, which shows that the method used to choose the implants does not interfere with the degree of satisfaction.

The scar is an important variable to be explained to the patient in the preoperative consultation, considering the change in location according to one's culture: in the USA and Brazil, inframammary scars are more common; in China the axillary scar is more frequent ${ }^{6,8,9}$. In our study, in the $1^{\text {st }}, 6^{\text {th }}$ and $12^{\text {th }}$ months, the evaluation mean was higher than 85. Additionally, there was no statistical difference when comparing the periods. This confirms the patients' acceptance of the scar, even in the first postoperative month.

The choice made through anthropometric measures has been the routine in our service for several years. On the other hand, methods that directly include the patient in this choice have proved equally effective and can facilitate decision-making, as well as the sharing of the choice responsibility. This is likely to reduce reoperation rates for breast volume dissatisfaction after a few years. On the other hand, it does not reduce 
mandatory reoperation rates in rare complications such as a late seroma. Therefore, guiding patients about all risks inherent to the procedure is essential ${ }^{11}$.

New third-dimensional preoperative measurement techniques have been introduced in the market. These are devices with high added value, requiring company-specific software and hardware ${ }^{4}$. On the other hand, these devices are still under evaluation, and a dissatisfaction degree with the final result of around $25 \%$ has already been verified ${ }^{20}$.

Our study allowed us to conclude that augmentation mammaplasty with breast implant has a high index of satisfaction among the patients, but there was no difference in satisfaction in the postoperative period between the three breast volume measurement methods.

\title{
R E S U M O
}

\begin{abstract}
Objetivos: avaliar o grau de satisfação de pacientes submetidas à mamoplastia de aumento e comparar três métodos diferentes, fáceis, baratos e universais, de escolha pré-operatória de volume de implante mamário. Métodos: estudo prospectivo, realizado no Hospital Universitário Pedro Ernesto da Universidade do Estado do Rio de Janeiro, em 94 mulheres naturais do Rio de Janeiro, com idades entre 18 e 49 anos, e submetidas à cirurgia de mamoplastia de aumento com implante, por hipomastia. Todos os implantes eram texturizados, com base redonda e projeção alta e foram introduzidos na loja retroglandular, por via inframamária. As pacientes foram divididas em três grupos: Controle, Silicone e MamaSize ${ }^{\circledR}$, com 44, 25 e 25 pacientes, respectivamente. Foram realizados questionários de satisfação nos períodos pré e pós-operatórios pelo mesmo avaliador, através de escala analógico-visual, em que 0 significava muito insatisfeita e 100 significava muito satisfeita para as quatro variáveis: forma, tamanho, simetria e consistência. No período pós-operatório avaliou-se também o grau de satisfação com a cicatriz cirúrgica. Resultado: quando comparados os graus de satisfação do pré-operatório com os do pós-operatório, houve diferença em todas as variáveis dos três grupos, com significância estatística. Entretanto, quando comparados os dados dos pós-operatórios entre si, não houve diferença significativa. O grau de satisfação com a cicatriz cirúrgica foi elevado. Conclusão: a mamoplastia de aumento com implante teve um grande índice de satisfação entre as pacientes. No entanto, não houve diferença no grau de satisfação no período pós-operatório entre as três metodologias de mensuração de volume mamário.
\end{abstract}

Descritores: Mamoplastia. Satisfação do Paciente. Cirurgia Plástica. Implantes de Mama. Percepção de Tamanho.

\section{REFERENCES}

1. isaps.org [Internet]. New York: The International Society of Aesthetic Plastic Surgery (ISAPS); c2017 [cited 2017 June 27] Available from: http://www.isaps.org/Media/ Default/Current\%20News/GlobalStatistics2016.pdf.

2. Saariniemi KM, Helle MH, Salmi AM, Peltoniemi HH, Charpentier P, Kuokknen HO. The Effects of Aesthetic Breast Augmentation on Quality of Life, Psychological Distress, and Eating Disorder Symptoms: A Prospective Study. Aesthetic Plast Surg 2012;36(5):1090-5.

3. Handel N, Cordray T, Gutierrez J, Jensen JA. A LongTerm Study of Outcomes, Complications, and Patient Satisfaction with Breast Implants. Plast Reconstr Surg. 2006;117(3):757-67.

4. Epstein MD, Scheflan M. Three-dimensional Imaging and Simulation in Breast Augmentation: What is the current state of the art? Clin Plastic Surg. 2015;42(4):437-50.
5. Hidalgo DA, Spector JA. Preoperative Sizing in Breast Augmentation. Plast Reconstr Surg. 2010;125(6):17817.

6. Psillakis JM, Facchina PH, Kharmandayan P, Trillo L, Canzi WC, Aguiar HR. Review of 1,447 Breast Augmentation Patients Using PERTHESE Silicone Implants. Aesthetic Plast Surg. 2010;34(1):11-5.

7. Spear SL, Murphy DK, Slicton A, Walker PS, Inamed Silicone Breast Implant U.S. Study Group. Inamed Silicone Breast Implant Core Study Results at 6 Years. Plast Reconstr Surg. 2007;120(7 Suppl. 1):S8-16.

8. Sun J, Liu C, Mu D, Wang K, Zhu S, He Y, Luan J. Chinese Women's Preferences and Concerns regarding Incision Location for Breast Augmentation Surgery: A Survey of 216 Patients. Aesthetic Plast Surg. 2015;39(2):214-26.

9. Somogyi RB, Brown MH. Outcomes in Primary Breast Augmentation: A Single Surgeon's Review of 1539 Consecutive Cases. Plast Reconstr Surg. 2015;135(1):87-97. 
10. Zelken J, Cheng MH. Asian Breast Augmentation: A Systematic Review. Plast Reconstr Surg Glob Open. 2015;3(11):e555.

11. Franco T, Franco D. Seroma tardio após implantes mamários de silicone: três formas diferentes de apresentação, evolução e conduta. Rev Bras Cir Plást. 2013;28(2):247-52.

12. Schmitt WP, Eichhorn MG, Ford RD. Potential cost of breast augmentation mammaplasty. J Plast Reconstr Aesthet Surg. 2016;69(1):55-60.

13. Tebbetts JB. A system for breast implant selection based on patient tissue characteristics and implant-soft tissue dynamics. Plast Reconstr Surg. 2002;109(4):1396-409.

14. França ALF, Scevola MCO, Fachin SD, França PF, França NC. Mamasize: A new auxiliary instrument in the planning of enlargement mammaplasty. Rev Soc Bras Cir Plást. 2005;20(4):204-6.

15. Nahas FX, Solia D, Ferreira LM, Novo NF. The Use of Tissue Adhesive for Skin Closure in Body Contouring Surgery. Aesthetic Plast Surg. 2004;28(3):165-9.

16. Quinn JV, Drzewiecki AE, Stiell IG, Elmslie TJ. Appearance Scales To Measure Cosmetic Outcomes Of Healed Lacerations. Am J Emerg Med. 1995;13(2): 229-31.

17. Adams WP Jr, Small KH. The Process of Breast
Augmentation with Special Focus on Patient Education, Patient Selection and Implant Selection. Clin Plastic Surg. 2015;42(4):413-26.

18. Dionyssiou DD, Demiri EC, Davison JA. A simple method for determining the breast implant size in augmentation mammaplasty. Aesthetic Plast Surg. 2005;29(6):571-3.

19. Pechter EA. A new method for determining bra size and predicting postaugmentation breast size. Plast Reconstr Surg. 1998;102(4):1259-65.

20. Cruz NI. Patient satisfaction with 3D simulation of breast augmentation surgery. P R Health Sci J. 2015;34(2):108.

Received in: 26/07/2017

Accepted for publication: 23/11/2017

Conflict of interest: none.

Source of funding: none.

\section{Mailing address:}

Rafael Daibert de Souza Motta

E-mail: rdsmotta@hotmail.com /

rafaeldsmotta@gmail.com

\section{(cc) BY}

